\title{
A BRIEF STUDY ON BATS OF POKHARA VALLEY
}

\author{
Narayan P. Koju ${ }^{1, *}$ and Mukesh K. Chalise, $\mathbf{P h D}^{2}$ \\ ${ }^{1}$ Khwopa College, Bhaktapur \\ ${ }^{2}$ Central Department of Zoology, Tribhuvan University
}

\begin{abstract}
There is very less information on bats in Nepal. Pokhara valley provides suitable habitat for both microchiroptera and mega-chiroptera. This valley has variable topographical features and climatic conditions, which is favorable for bats. A two week long observation was carried out on bats and their roosting sites in December 2010 and February 2011. Eleven roosting sites were observed and three species of bat were captured from different roosting sites. Mist net and Gully net were used to capture the bats. Bats in Chamero Gupha were counted and found to have density of 94.57 per sq. meter; population of Pteropus giganteus was counted in Radha Krishna Tole.
\end{abstract}

Keywords: Bats, Chiroptera, Roost, Nocturnal, Cave, Threat

\section{Introduction}

Bats are only flying mammal whose forelimbs are modified into wings. Bats belong to order Chiroptera which is the second largest order among twenty six mammalian orders in the world. It has 1,117 species throughout the world (Srinivasulu et. al. 2010). The Order Chiroptera is divided traditionally into two Suborder- Mega-chiroptera (large bat) and Micro-chiroptera (small bat).

Bats are widely distributed and are recorded throughout the world except Antarctica and a few oceanic islands (Mickleburgh et. al. 2002). Bats are one of the least studied mammals as they are nocturnal, so usually researchers feel difficulties in its detail study due to different reasons. Recent record shows that Nepal has fifty three species of bats (SMCRF, 2010) which is about five percent of the world bat diversity and over forty percent of south Asian bat diversity. Bats play significant role in ecosystem as they help in pollination and seed dispersal. They are disease controller and also destructive due to the pest habit. Animal use is still continued for income generation, nutritional supplement, and for the social and cultural needs in

*Corresponding author: Narayan P. Koju,

Contact Address: Khwopa College, Bhaktapur

Email:npkoju_2003@yahoo.com

(Received date: 2011 Sep 01

Accepted date: 2011 Nov 24) different parts of the world. Bush meat, in particular, offers a number of benefits to forest-dwelling populations. It is an easily traded resource as it is transportable, has a high value/weight ratio and is easily preserved at low cost. It often represents both the primary source of animal protein and the main cash-earning commodity for the inhabitants of the humid forest regions of the tropics. In Nepal, hunting is one of the important aspects of people's food quest and income generation. Hunting is mostly done when people are free from their agricultural fields or routine schedule. Their targets are mammals, birds and some reptiles. In Nepal people use the animals for different purpose such as nutrition, income generation, religious rituals and medicinal use (Chalise 2010). Some ethnic communities of Nepal use bats as food which is good alternative source for meat protein (Koju, 2011). Due to lack of awareness, habitat encroachment and habitat loss, bats' population is threatened in Nepal (Koju and Chalise 2010, SMCRF, 2010).

Pokhara valley provides suitable habitat for both micro-chiroptera and mega-chiroptera. This valley has variable topographical features and climatic conditions which is favorable for bats. It has numerous caves and gorge that provide safe habitat 
for bats. Suburban areas of Pokhara valley consists of different sizes of orchard farm and floriculture. The valley floor also consists of some wilder areas and parklands that provide wild fruits and flowers which is very important for fruit bat (megachiroptera) population. Abe (1971) explored three species of bats in Pokhara, and Puspa Raj Acharya had conducted a study on distribution of roosting and survival threats of bats in Pokhara valley with reference to Chamero cave in 2006.

\section{Methodology}

The study was carried out for two weeks in Pokhara Sub-Metropolitan city a week each in December 2010 and February 2011. Information about bats and its roosting site was collected from local people from different parts of Pokhara and literature review.

Questionnaires were asked to local people and cave guides to acquire the information on bats' specific roosting site, population, types and to understand locals' opinion towards bat. Scan sampling method (Altmann, 1974; and as practiced by Chalise, 2003; Koju, 2008; Koju and Chalise 2010) was applied to count the population. Bats were counted inside the cave with the help of light source and using quadrate of $2 \mathrm{~m} \times 2 \mathrm{~m}$. Mist net $(7 \mathrm{~m} \times 3 \mathrm{~m})$ was used to trap the bats near the water resources for close identification at species level. The bat specimens were captured from' Mahendra cave' and 'Chamero cave' using Gully net. These specimens were identified with the help of reference picture from scientific books supplemented by the local's name and identification clue.

\section{Population density}

Population density $=X / \mathrm{A}$

$X=$ population of bats

$\mathrm{A}=$ Total area of cave (ceiling)

\section{Study Area}

Pokhara valley lies in Kaski district $\left(83^{\circ} 40^{\prime}\right.$ to $84^{\circ} 12^{\prime}$ and $28^{\circ} 06^{\prime}$ to $28^{\circ} 36^{\prime}$ ) located at the centre of the Western Development Region of Nepal. Its elevation ranges from $450 \mathrm{~m}$ to $969 \mathrm{~m}$ above sea level (Fig. 1). It has about $45 \%$ forest in total district area (DDC, 2005) and has a humid subtropical climate owing to the low elevation. Its mean temperature is always above $56^{\circ} \mathrm{F}\left(15^{\circ} \mathrm{C}\right)$ with summer temperature exceeding $30^{\circ} \mathrm{C}$. The region is exposed both to the summer monsoon and winter jet-streams and those two air masses give a distinct seasonal characters. The valley has the highest precipitation rates of the country over $4000 \mathrm{~mm}$ annually. The main rainfall occurs during the summer monsoon period that is complemented by winter falls. Pokhara valley is the valley of lakes, rivers, caves and gorges. Mahendra cave, Chamero cave, Gupteshower Cave and Sita cave are famous caves where different species of bat roosts. In addition to caves and gorge, bats in Pokhara also inhabit in small forest patches, garden, river and lake banks. The rapid physical construction, urbanization and mushrooming industrialization within the habitat and high frequency of visitors in

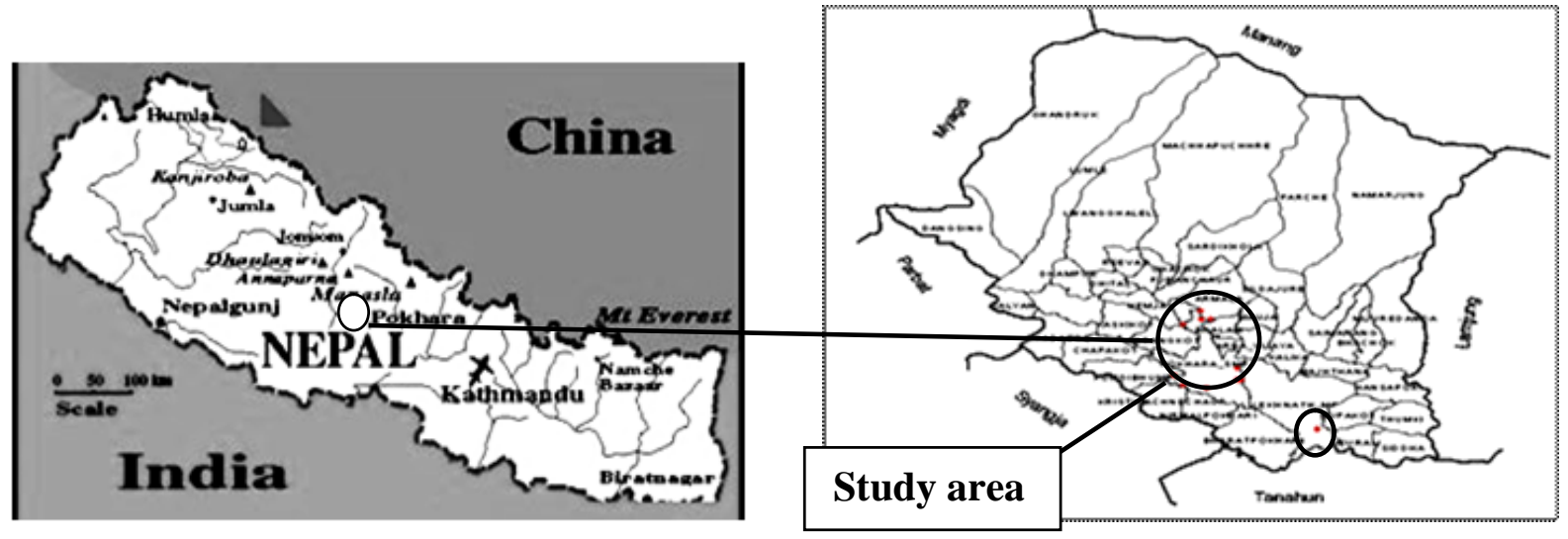

Fig.1. Location map of study area in Nepal 
caves are disturbing the bats population in Pokhara valley.

\section{Result}

\subsection{Distribution of Roosting sites in Pokhara}

During the field visit bats were observed from the following locations of Pokhara (Table1).

Table 1: GPS Location coordinates and accessibility of different caves in Pokhara

\begin{tabular}{|c|c|c|}
\hline .N. & $\begin{array}{c}\text { Roosting sites and area } \\
\text { in Pokhara }\end{array}$ & GPS L \\
\hline 1. & Mahendra Cave & $\begin{array}{l}83^{\mathrm{O}} 58 \cdot 36.7 " \mathrm{E} \\
28016 ' 19.6 " \mathrm{~N}\end{array}$ \\
\hline 2. & \begin{tabular}{|l|}
$\begin{array}{l}\text { Bat cave } \\
\text { (Pokhara - 16 Batule chaur) }\end{array}$ \\
\end{tabular} & $\begin{array}{l}83^{\mathrm{O}} 59^{\prime} 32.4^{\prime \prime} \mathrm{E} \\
28015^{\prime} 48.3^{\prime \prime} \mathrm{N} \\
\end{array}$ \\
\hline 3. & \begin{tabular}{|l|}
$\begin{array}{l}\text { Gupteswor cave } \\
\text { (Pokhara -17 Chorepatan) }\end{array}$ \\
\end{tabular} & $\begin{array}{l}84^{0,} 41.3^{\prime \prime} \mathrm{E} \\
28010^{\prime} 53.6^{\prime \prime N} \\
\end{array}$ \\
\hline 4. & \begin{tabular}{|l} 
Crazy Cave \\
(Armala -6 Siplekuna)
\end{tabular} & $\begin{array}{l}83^{\mathrm{O}} 58^{\prime} 52.9^{\prime \prime} \mathrm{E} \\
28016^{\prime} 17.3^{\prime \prime} \mathrm{N} \\
\end{array}$ \\
\hline 5. & $\begin{array}{l}\text { Peace cave } \\
\text { (Hemja - 2, Kaski) }\end{array}$ & $\begin{array}{l}3^{\mathrm{O}} 59 \text { '32.6"E } \\
28011 \text { '20.3"N }\end{array}$ \\
\hline 6. & $\begin{array}{l}\text { Putali Cave } \\
\text { (Bhalam-2, Kaski) }\end{array}$ & $\begin{array}{l}83^{\mathrm{O}} 59 \cdot 34.3^{\prime \prime} \mathrm{E} \\
28012^{\prime} 36.7^{\prime \prime} \mathrm{N} \\
\end{array}$ \\
\hline 7. & $\begin{array}{l}\text { Ke } \\
\text { Kaski) }\end{array}$ & $\begin{array}{l}83^{\mathrm{O}} 59^{\prime} 33.5^{\prime \prime} \mathrm{E} \\
28001^{\prime} 44.2^{\prime \prime N} \\
\end{array}$ \\
\hline 8. & $\begin{array}{l}\text { Powerstation cave } \\
(\text { Pokhara - 17) } \\
\end{array}$ & \begin{tabular}{|l|}
$84^{\mathrm{O}} 43^{\prime} 9 " \mathrm{E}$ \\
$28010^{\prime} 43.2^{\prime \prime} \mathrm{N}$ \\
\end{tabular} \\
\hline 9. & \begin{tabular}{|l} 
Sita cave \\
(Lekhnath -14 Chainpur)
\end{tabular} & $\begin{array}{l}84^{\mathrm{O}} 0^{\prime} 19.2^{\prime \prime} \mathrm{E} \\
28014^{\prime} 50.7^{\prime \prime N} \\
\end{array}$ \\
\hline 10. & \begin{tabular}{|l}
$\begin{array}{l}\text { Radhakrishna Tole } \\
\text { (Pokhara -18 Dhumre) }\end{array}$ \\
\end{tabular} & $\begin{array}{l}83^{\mathrm{O}} 5^{\prime} 49.4 " \mathrm{E} \\
28015 \cdot 29.3^{\prime \prime N}\end{array}$ \\
\hline 11. & \begin{tabular}{|l|} 
Pokhrel Thar \\
(Pokhara- 18, Chineadanda)
\end{tabular} & $\begin{array}{l}84^{\mathrm{O}} 03^{\prime} 14.0^{\prime \prime} \mathrm{E} \\
28014^{\prime} 48.9^{\prime \prime} \mathrm{N}\end{array}$ \\
\hline
\end{tabular}

\subsection{Collection of Bat Specimen population census and Identification}

\subsubsection{Mahendra Gupha (cave)}

This is the foremost popular cave of Nepal. It is located at Pokhara-16; Batulechaur about $5 \mathrm{~km}$ north of Pokhara centre (Acharya, 2007). The complete cave is developed below the course conglomerate of the cap-rock. The cave has two main alleys at west and north east. The alley of the west is further divided into two sub alleys which are long, narrow and very dark. The main central part of cave was supplied by electric illumination and there is a sculpture of Hindu god Shiva. Hipposideros pomona was recorded by Bates and Harrison (1997); Hipposideros armiger was reported by Giri (2009) and Rhinolophus affinis was reported by Bates and Harrison (1997) and Giri (2009) from this cave. However, we observed only seven bats in the cave. Among them we captured three species of bats. All captured species were male. They were Hipposideros armiger, Rhinolophus marcotis and Rhinolophus affinis. We did not notice Hipposideros pomona during the study. We recorded for the first time the presence of Rhinolophus marcotis in Mahendra cave.

\subsubsection{Chamere Gupha (cave)}

Chamere Gupha (cave) is located $800 \mathrm{~m}$ west near Mahendra cave. It is $25 \mathrm{~m}$ in length, about $9 \mathrm{~m}$ wide and about $5 \mathrm{~m}$ height. Bat was roosting in area of length $17 \mathrm{~m}$ and breadth $8 \mathrm{~m}$ in February. The population and roosting area were less than this in the month of December. In February, we counted the total population of bats roosting in the cave by using $2 \mathrm{~m} \times 2 \mathrm{~m}$ quadrates. Quadrates were placed randomly at five places in roosting area. The total population was counted 21,280 with its density of 94.57 individuals per square meter.

In Chamero cave five specimens of bats were caught. Among them four (one adult male and three female) were Hipposideros armiger and one was male Rhinolophus marcotis. Few infant Hipposideros armiger were observed. In the roosting sites, the gap between two bats was about $35 \mathrm{~cm}$. The bats were roosted uniformly and infants (smaller size) were roosting in between mature bats (larger size).

\subsubsection{Gupteswor Cave}

This cave is located about $3 \mathrm{~km}$ southwest of Pokhara centre. It is also called Davis' fall or Patale Chhango. It is the longest cave of Nepal and of Indian subcontinents E- 700m, ID-2559 m, D- 48m (Grebuer, 1982 ). The cave consists of 3 large chambers. Among the present bats only two species Hipposideros armiger and Rousettus leschenaulti were reported from the second chamber by Acharya 
(2007). But there was no bat roosting during our visit in December 2010.

\subsubsection{Sita cave}

This cave is located near Begnas Lake $15 \mathrm{~km}$ north east from the centre of the Pokhara. The cave was in a cliff, so it's hard to go inside the cave but stain of fecal matter was observed at the entrance of the cave in December 2010.

\subsubsection{Radhakrishna Tole and Pokhrel Thar}

Pteropus giganteus were observed roosting in Radhakrishna tole which is located at $8 \mathrm{Km}$ south east from centre of Pokhara. There are three roosting sites; two near the paddy field and one about $150 \mathrm{~m}$ west from former roosting site. Bats were roosting in Bamboo (Dendrocalamus hemiltonii), Pakhuri (Ficus glaburima), Simal (Bombax ceiba). Local respondent in Radhakrishna Tole comment that those bats arrived there three years ago from $3 \mathrm{~km}$ north east area. They left previous roosting site as land owner cut all trees where they used to roost. We counted 326 bats and observed that most of them roosted in Simal tree (Bombax ceiba). There were only seven medium size Simal tree. They roosted in the private residential houses, trees, temples and a school. According to land owner, the population of bats is decreasing and they left the roosting site in summer season (migration!) and they sometimes return to the roosting site with apple fruits. Apple is found about $80 \mathrm{~km}$ (aerial distance) to north from Pokhara. They feed on leaves and flower of Simal tree and sometimes raid on fruits especially banana, guava and papaya of local area.

\subsubsection{Bank of Fewa Lake}

Mist net was used to capture bats at night near Fewa Lake. Net was placed near the bank of lake which was the garden habitat. However, no bats were captured within two days of net setting.

\subsection{Threats to bat at study area}

Habitat loss, habitat encroachment and other anthropogenic activities are the most crucial threat to bats' survival in Pokhara. Chamere cave, Mahendra cave and Gupteshwor cave are main sites for tourist's flow which is popular and common bats roost sites. However, due to human intervention, population and species diversity of bats are decreasing in Pokhara. Increasing human settlement area, construction of building and industries are the main cause perceived to decrease the food sources for mega-chiroptera.

\section{Conclusion}

We have very less information on bats and their distribution throughout Nepal. Pokhara is very suitable habitat for bats. Eleven roosting sites were explored with five different species of bats. Among them one species, Pteropus giganteus is megachiroptera and the rest are micro-chiroptera. Bats in Pokhara Valley are under threat by habitat loss and disturbance. Rousettus leschenaultia reported by Acharya, 2006 was not observed in Gupteswor Cave during my field work.

\section{Acknowledgement}

We are thankful to Khwopa College and students of M.Sc first year 2010 batch for help in field work. Special thanks render to local people of Radha Krishna Tole for their support and help and SMCRF for providing mist net for study.

\section{References}

[1] Abe, H. 1971, Small Mammals of Central Nepal. Mammalia. Jour. Fac. Agr., Hokkaido Univ., Sapporo, japan, Vol. 56: pp 396-403

[2] Acharya, P.R. (2006). Distribution of Roosting and survival threats of bats in Pokhara Valley with reference to species and population survey at Chamere Gupha. A dissertation submitted to the Central Department of Zoology, TU, Kritipur, Kathmandu, Nepal

[3] Altmann, J (1974). Observation of study of behavior: sampling methods, behavior, 49: pp 227-265.

[4] SMCRF (2010). Bats of Nepal A study guide, Small mammal's conservation and research foundation

[5] Bates Paul J. J. and Harrison D. L. (1997). Bats of Indian subcontinent; Harrison Zoological Museum Publication, India, pp 50-215 
[6] Chalise, M.K (2003). Assamese monkeys (Macaca assamensis) in Nepal. The journal of the IUCN/SSC/ PGG primate Conservation Vol. 19; 99-107p. Conservation International, USA

[7] Chalise M K. (2010). Usage of animals by the rural people in reference to Nepal. Sustainable Use of Biological Resources in Nepal, pp. 145-151.

[8] DDC (2005). Annual Report of Kaski district, District Development Committee, Kaski, Pokhara.

[9] Giri, B.K (2009). Habitat suitability mapping and species identification of chiroptera: a case study from Kaski District, Nepal. Thesis submitted to IOF, Tribhuvan University, Pokhara.

[10] Grebuer, H. Daniel-(1981/1982) Caves of India and Nepal: including the result of spelaologische sudasian expedition, Germany.

[11] Gurung H. (1965): Pokhara valley: a Geographic survey. Nepal Geographical Society.

[12] Koju, N. P. (2008). Population status, general behaviour and threats of flying fox (Pteropus giganteus) in Sallaghari, Bhaktapur, Nepal. A Dissertation submitted to central department of Zoology, TU, Kritipur, Nepal

[13] Koju, N.P. (2011). Chepang ra Chamero. Bigyan Lekhmala, Nast Monthly News Letter, vol.362: pp 4-6

[14] Koju, N. and Chalise M K_(2010). Diurnal observation of population and general behavior of Flying fox (Pteropus giganteus) in Sallaghari, Bhaktapur, Nepal. Journal of Natural History Museum, TU, Kathmandu. Vol. 25: pp 256-265.

[15] Koju, N. and Chalise M K_(2011). Population pattern of Flying fox (Pteropus giganteus) in Sallaghari, Bhaktapur, Nepal. Special issue on the occasion of $16^{\text {th }}$ Wildlife Week, 2068. DNPWC/Govt. of Nepal, pp 1-5

[16] Mikelburgh, S. P., Hutoson, A. M.and Racey P. A (Ed) (1992). World Fruit bats: An action plan for their conservation. IUCN/ SSC chiroptera specialist group IUCN Gland, Switzerland. Museum Publication 1997.

[17] Srivasulu, C.. Racey, P. A and Mistry, S. 2010. A key to the bats of South Asia. Journal of threatened taxa 2 (7): pp 1001- 1076. 